\title{
Improving Community Health and Nutrition Services: Role of Elected Leaders in Monitoring and Improving Service Delivery
}

\author{
Anjali Nayyar ${ }^{1}$, Sita Shankar Wunnava ${ }^{2}$, Anuj Ghosh ${ }^{3 *}$, Nidhi Dubey ${ }^{4}$, Deepak Mishra ${ }^{5}$, Indira \\ Behara Tankha ${ }^{6}$ \\ ${ }^{I}$ Executive Vice President, Global Health Strategies \\ ${ }^{2}$ Public Health Consultant \\ ${ }^{3}$ Director, Global Health Strategies \\ ${ }^{4}$ Vice President, Global Health Strategies \\ ${ }^{5}$ Manager, Global Health Strategies \\ ${ }^{6}$ Senior Director, Global Health Strategies
}

*Corresponding Author: Anuj Ghosh, Director, Global Health Strategies, Email: aghosh@global healthstrategies.com

\begin{abstract}
Monitoring services and accountability is critical for improving change in access to quality health and nutrition services at the community level. Leadership at the grassroots level represents and is directly in contact with the community. In Uttar Pradesh, India, an innovative project improved the capacity of village elected representatives, Gram Pradhans and select community members by establishing a feedback mechanism and linking them to the Members of the legislative assembly from the project district to prioritize health services. This was to enable them to monitor, provide feedback on roadblocks and address gaps leading to improved services for reproductive, maternal, new-born, child health and nutrition. The pilot intervention showed that when trained, equipped with the requisite skills and provided a supportive environment, grassroot leaders, can become a potent force of change. We documented how elected leaders can be engaged to work with government officials at various levels to set up monitoring, and redressal mechanisms to improve service delivery and demand. Quantitative and qualitative assessment reveals that this intervention is an important building block in the last mile service delivery, for health and nutrition programs in India.
\end{abstract}

The article discusses the processes, outcomes, learnings and outlines a path for scale up.

Keywords: Improving Health Services, Elected Village Leaders (Gram Pradhans), Capacity Buildingleadership development, Community Engagement, Uttar Pradesh, India, Monitoring Mechanisms, Accountability

Abbreviation: ANM: Auxiliary Nurse Midwife, ASHA: Accredited Social Health Activist, ANC:Antenatal Care, BDO: Block Development Officer, CELD: Community Engagement and Leadership Development, DISHA: District Development Coordination and Monitoring Committee, DLVMC: District Level Vigilance and Monitoring Committee, DM: District Magistrate, FLW: Front-line Worker, GP: Gram Pradhan, GHS: Global Health Strategies, ICDS: Integrated Child Development Services, MOIC: Medical Officer In-charge, MP: Member of Parliament, MLA: Member of Legislative Assembly, MLC: Member of Legislative Council, NHM: National Health Mission, PRIs: Panchayati Raj Institutions, QED: Quality, Equity and Dignity, RMNCH+A: Reproductive, Maternal, Newborn, Child and Adolescent Health, VHND: Village Health and Nutrition Day, VHSNC: Village Health, Sanitation and Nutrition Committee, UP: Uttar Pradesh

\section{INTRODUCTION}

Recognition of the importance of quality health services for all, especially the most vulnerable, is crucial. Universal health coverage is defined (by World Health Organization-WHO), as ensuring that all people have access to required health services (including prevention, promotion, treatment, rehabilitation and palliation) of sufficient quality to be effective while also ensuring that the use of these services does not expose the user to financial hardship. 
Universal health coverage has therefore become a major goal for health reform in many countries. India has witnessed widening differentials in health outcomes mainly caused by inequities in socio-economic conditions and in the provision and access to health services [1]. A Lancet study conducted in 2017 placed India at the $145^{\text {th }}$ position amongst 195 nations in terms of providing quality and accessibility healthcare. The study brought forth striking subnational disparities -- with Goa and Kerala, each exceeding 60 points while Assam and Uttar Pradesh (UP) was rated the lowest, with each scoring below 40. Key areas that require attention to deal with these issues include an introduction of new ways to monitor progress toward equitable services, feedback mechanisms to address gaps and barriers, and strengthen democracy in the functioning of public health delivery systems (Baru, et al 2010). A cardinal principle for good governance is accountability. A multi-pronged partnership between those who can develop or revise policies, who bring technical knowledge and resources and those who supervise on-ground initiatives while acknowledging problems and seeking solutions is the key to equitable, multisectoral primary health care [2].

Uttar Pradesh, the most populous state $\left[^{3}\right]$ in India, presents a complex social and political environment that requires a tailored approach to bring about any improvement in its health and development landscape. The state plays a critical role in impacting India's overall national health outcomes, often lowering national averages of critical health indicators $\left[{ }^{4}\right]$. Under

[1] Universal health coverage embodies three related objectives: equity in access to health services - those who need the services should get them, not only those who can pay for them; that the quality of health services is good enough to improve the health of those receiving services; and financial-risk protection - ensuring that the cost of using care does not put people at risk of financial hardship.

[2] Lancet 2017; 390: 231-66 Published Online May 18, 2017 http://dx.doi.org/10.1016/ S0140-6736; Institute for Health Metrics and Evaluation, University of Washington, 23015 th Avenue, Suite 600, Seattle, WA 98121, USA; Vol 390 July 15, 2017; ARTICLES|VOLUME 391, ISSUE 10136, P2236-2271, JUNE 02, 2018. [performance was measured on the Healthcare Access and Quality (HAQ) Index

[3] Over 20 crores, i.e. around 200 million people

[4] The state still lags behind in key health indicators including Infant Mortality Rate (IMR) and Maternal
India's National Health Mission (NHM), decentralized health planning is an integral strategy wherein the Gram Pradhans (GP) or grassroots elected representatives play a key role in improving health and nutrition services at the panchayat level. The GP $\left[{ }^{5}\right]$ is the president of the Village Health Sanitation and Nutrition Committee (VHSNC) $\left[^{6}\right]$ and has the ability to channelize the expertise of the VHSNC members, including frontline workers, to achieve health and nutrition goals. Hence, for improved accountability and governance, it is imperative that these key players understand and prioritize the health and nutrition needs of the community, judiciously leverage available financial resources, and devise community healthcare solutions with other stakeholders such as local political leaders and relevant government departments. GP also play a key role in monitoring the Village Health and Nutrition Days (VHNDs) $\left.{ }^{7}\right]$ and ensuring its

Mortality Ratio (MMR), which stand at 64 and 201 as against the national average of 41 and 130, respectively. Half of all women aged 15-49 years in the state are anaemic. Approximately $46 \%$ and $18 \%$ of all children under five are stunted and wasted respectively (NFHS-4). Almost half the children (between 12-23 months) in the state have not received full immunization (NFHS-4). The gap between the national average and the state on health indicators varies from $10 \%-70 \%$.

[5] Gram Pradhan or sarpanch is the elected head of a gram panchayat (transl. 'village council') or village panchayat. It is the only grassroots-level of panchayati raj which is a formalised local selfgovernance system in India at the village or smalltown level

[6] A key intervention introduced by National Rural Health Mission, VHSNCs are an important mechanism to ensure community participation at all levels, which include participation of beneficiaries, in supporting health activities, in implementing, and even in monitoring and action based planning for health programs. The VHSNC functions under the ambit of the Panchayat Raj Institutions (PRI). It would be a subcommittee or a standing committee of the panchayat. An important objective is to Equip Panchayats with the understanding and mechanisms required for them to play their role in governance of health and other public services and provide leadership to the community for collective action to improve health status

[7] VHND is an important platform for interfacing between the community and the health system. The VHND is organized once every month at the Aanganwadi Centre in the village. Key services provided are: reproductive health including FP, maternal \& child health, communicable diseases, 
proper functioning according to the government guidelines, including holding frontline workers accountable. They are instrumental in generating demand and advocating with (i) Communities to avail of health and nutrition services, (ii) Block and district officials to address stock outs of essential commodities/medical supplies, infrastructure and human resource issues, (iii) Members of the Legislative Assembly (MLAs) and Member of Parliament (MPs) to ensure improvement in services of health and nutrition through regular monitoring visits and representation at block, district and state level meetings.

Recent research has highlighted the role of bottom-up mechanisms for improving the accountability of local officials through community monitoring (Bjorkman and Svensson 2009), demand for transparency and information on the utilization of public funds by local governments, viz. through the Right to Information Act initiative in India. The 73rd amendment of the Constitution, enacted in 1992, decentralized the administration of rural areas to a three-tier Panchayat system to ensure grassroots participation and give voice to the local communities. Hence, there are multiple dimensions on which citizens' demand for services can be enhanced. Amongst formal enforcement mechanisms, reducing the role of intermediaries for service delivery will enhance the effectiveness of the system. Some evidence suggests that decentralized governance is better for long term growth due to greater conservation of local resources.

Recognizing that the Panchayati Raj Institutions (PRIs) $\left.{ }^{8}\right]$ are the platform to promote decentralized health planning, Global Health Strategies (GHS) developed an innovative initiative called the Community Engagement and Leadership Development (CELD), that adopted a bottom-up approach which engaged and empowered GP to monitor programs and

nutrition, sanitation etc. The proper organization of the VHND is the most crucial component of NRHM for guaranteeing service provision at the village level, hence effective supervision and monitoring are essential components.

[8] Panchayati Raj is a system of rural local selfgovernment in India. It has been established in all the states of India by the acts of the state legislature to build democracy at the grass root level. It is entrusted with rural development and was constitutionalized through the 73rd Constitutional Amendment Act of 1992. ensure the availability, accessibility and last mile reach of health and nutrition services. The CELD initiative was implemented for about two years (January 2017- December 2018) in five districts across 329 gram panchayats [ $\left.{ }^{9}\right]$ spanning /covering 432 revenue villages $\left[10^{10}\right.$, to showcase the role that community institutions and GP can play in improving service delivery and utilization of health and nutrition services at the grassroots level, through effective monitoring and improved accountability leading to better governance.

The CELD initiative in collaboration with the government, aimed to build the capacity of elected leaders as champions in supporting, monitoring and advocating for services provided at the community-level. The aim was to empower champions at the village level for sustaining quality health and nutrition services, strengthen and elevate the voices of communitylevel champions at various forums, build community capacity to establish sustainable monitoring and accountability mechanisms to ensure wider reach and uptake of health and nutrition services. It also helped create a platform for collaboration with various government departments to improve last mile service delivery.

The program recognized the crucial role state and national political leaders play in ensuring the implementation of appropriate policies and finances, maintaining adequate stocks/ provisions and addressing roadblocks and building demand at multiple levels in the state, district and village. Towards this end, the CELD initiative engaged with Members of Legislative Assembly / Council (MLAs/MLCs), Members of Parliament (MPs), and district/block level government officials. The objectives were to build their understanding and appreciation of the importance of strengthening community level Reproductive, Maternal, Newborn, Child and Adolescent Health (RMNCH+A) and nutrition initiatives and motivating GP to act as effective monitors to strengthen VHSNCs and VHNDs. The key approach was to select MPs/MLAs who showed the potential of becoming early adopters/change agents and to maintain their

[9] Districts: Kannauj, Allahabad, Pilibhit, Lakhimpur Kheri, Jhansi (one block in each district); Population covered: 10 lakhs/1 million

[10] A Revenue Village is a small administrative region in India, a village with defined borders. One revenue village may contain many hamlets. 
interest through regular interaction. They were encouraged to participate actively in the District Level Vigilance and Monitoring Committee (DLVMCs, also known as DISHA- District Development Coordination and Monitoring Committees) meetings and motivate other elected representatives too. Profiles of districts that matched with the constituencies of the interested MPs/MLAs were developed and shared with them. Field visits were organized and the elected leaders were shown how to compare the profiles with the situation on ground. Meetings with the District Magistrates (DM) $\left[{ }^{11}\right]$ and the GPs were facilitated and with their help two block level platforms viz interdepartmental convergence platform $\left[{ }^{12}\right]$ and interface block level meetings $\left[{ }^{13}\right]$, were created under the CELD initiative for improved coordination. The project had envisaged the

[11] A district magistrate, often abbreviated to DM, is an Indian Administrative Service (IAS) officer who is the senior most executive magistrate and chief in charge of general administration of a district in India.

[12] Objective of the inter-departmental convergence platform was to achieve inter-departmental convergence among departments at the block level for improved coordination. These meetings are held under the chairmanship of Block Development Officer (BDO). Inter departmental convergence meetings were designed for the departments of Health, Education, PRI and ICDS to come together at a designated time under one roof. This coordination mechanism provided an opportunity for the departments to find solutions for some of the challenges faced in the delivery of health and nutrition services and reflect upon challenges raised by GP during interface meetings. The team facilitated 21 block level inter-departmental convergence meetings. A major achievement of holding these meetings was that the CMO in Kannauj issued a letter to MOICs, Deputy CMOs and Additional CMOs directing them to hold such meetings regularly at the block level.

[13] The block level Interface meetings provide a platform for the GP to raise issues related to the services and also share their achievements with Govt. officials from the Health/NHM, PRI and ICDS departments. It also gave an opportunity to officials to share their concerns and areas where the GP could support them. MLAs continue to use these meetings to encourage the GP towards strengthening VHSNCs and VHNDs. The team facilitated 16 block level interface meetings. Women Gram Pradhan participation was encouraged and regular engagement of political champions with PRI leaders, led to a marked improvement in their participation in these meetings. sensitization of 5 MPs/MLAs -- one per block/district -- but finally 14 political leaders were engaged, triple the number the project had committed to. Six political leaders visited the CELD intervention areas, twice each- i.e. in all 12 visits were undertaken. Five sensitized political champions (MPs) participated actively in DISHA meetings, from high priority districts. The key issues raised were related to the immunization coverage of children, the human resource situation of medical personnel, the status of issuance of the Ayushman Bharat Yojana cards; stock-taking of the status of malnutrition of children in the district was addressed and a chaupal (open panchayat meeting) was to be organized to list all severe and moderate cases of acute malnutrition and to highlight the need for an action plan. Need for regular meetings of the district nutrition committee were reiterated. A review of the data on Ante Natal Care(ANC) registration and adolescent girls' registration was also undertaken and they stressed on the importance of convergence and collaboration between the key departments.

For improving action on the ground, GP's were educated and trained about their roles and responsibilities to ensure that VHSNCs and VHNDs were operating regularly and effectively and they were utilizing the untied $\left[{ }^{14}\right]$ VHSNC funds for the health and nutrition needs of their community. They were made aware of the authority and responsibility vested in them for health and nutrition activities. Training workshops were held and on-ground supportive supervision was used to enable GP's to be effective leaders to monitor program implementation and ensure the accountability of frontline workers. A user friendly ' 15 hour-20 visit' capacity building curriculum was developed, for training GP's on requisite knowledge, attitude and skills to overcome existing ground-level challenges $\left[{ }^{15}\right]$, and was

[14] The concept of untied funds was introduced in 1988-89 with the objective to carry out the works of emergent nature which are normally not covered under the schemes decentralized at the district level. These funds are mainly allocated for filling up the missing gaps and for completing the in-complete public utility assets.

[15] Lack of knowledge and involvement of the Gram Pradhan in monitoring health and nutrition programs and the functioning of VHSNCs \& VHNDs, No convergence platform available at block level where GP can participate and discuss their 
carried out during one-to-one interactions with the GP. A toolkit containing a pocket book with essential messages on health and nutrition and a handout booklet containing important Government of India guidelines related to VHSNC, VHND, relevant schemes, the role and responsibilities of GP and a monitoring checklist [please refer to Annexure-1], was distributed to the trained GP. They were also counselled to assess the gaps and resolve issues in collaboration with the FLWs Use of mainstream media and social media has played an important role in showcasing the pivotal role elected leaders have played in transforming community level services in remote villages of UP.

A key focus was also to improve inter-sectoral convergence at the block level by organizing block level interface meetings under the chairmanship of the Block Development Officer (BDO). The meeting was attended by all GP's of the area with block level officials from line Departments-Health, Integrated Child Development Scheme (ICDS), Education and Panchayati Raj Institution. This provided a platform for the GP to raise issues related to the services and enable redressal, while also sharing their achievements. The exercise promoted accountability between departments to the representatives of the end users (i.e. the GP).

It also provided an opportunity for health officials to discuss concerns and areas where the GP's could support them to improve community level health and nutrition services. An effort was made, successfully, to involve more women GP's to attend these meetings and play a proactive role. Sensitized political leaders were encouraged to organize interface meetings in their constituencies. This leads to four elected representatives organizing two block level interface meetings each ( 8 in all), with GP in their constituencies resulting in sensitization of a large number of the GP/their representatives, including women GP. These interface meetings were documented and shared with the state government, resulting in the Chief Secretary issuing a Government Order to regularize the block level inter-sectoral convergence meetings

issues will relevant govt. officials, Limited or no awareness about government health programs/schemes among elected representatives, female Gram Pradhan not proactive in carrying out their responsibilities towards health and nutrition programs across the state of UP. The representatives also wrote advocacy letters to the Health Ministry, GoUP to replicate this initiative in other districts of UP.

This form of capacity building has helped elected representatives like, the GP, MP \& MLAs prioritize health and nutrition issues and honed their monitoring and advocacy skills. The clear outcomes of the initiative lead to GP better understanding of their roles and responsibilities, and highlighted the importance of using the monitoring checklist for every VHND visit, follow up on gaps found in the monitoring checklist with concerned officials or by utilizing VHSNC funds to procure necessary items, improved accountability of the frontline health and nutrition workers and better collaboration and linkages with government officials and senior political leaders. The functioning of community level platforms like the VHSNC and VHND have been strengthened to ensure effective implementation of health and nutrition programs, due to a better monitoring mechanism and accountability systems.

\section{Materials \& MethodS}

A ranking system was developed to assess the performance of the gram panchayats in the intervention area, by using a 10 -indicator $\left[{ }^{16}\right]$ grading method, based on which the Gram Panchayats were ranked during the intervention period on a frequency of three months. This evaluation aided in internal reporting of challenges faced by any Gram Pradhan in accomplishing indicators and further provided the scope of improving performance of the gram panchayat. The method used was a concurrent

[16] 1.VHSNC formed 2. VHSNC functioning as per Govt. guidelines 3. Gram Pradhan/representative participating in VHSNC meetings 4. Gram Pradhan / representative monitoring VHNDs 5. VHNDs organized as per the state guidelines 6. Matr Samiti functioning 7. Gram Pradhan/ representative taking initiative to strengthen VHNDs/health and nutrition services in panchayat 8. Gram Pradhan/ representative raising issue at block and district level 9.Conducting community awareness activity at village level and GP/other panchayat leaders utilizing social media platform for generating awareness on health and nutrition issues 10. GP/other panchayat leaders conducting community awareness activity at village level including utilizing social media platform for generating awareness on health and nutrition issues. The ranking criteria: 0-3: Poor performing (Red zone); >3-6: Medium performing (Yellow Zone); >6: High performing (Green zone) 
monitoring system. The 'action-reflectionmodified action' monitoring approach helped track the progress against the indicators identified for the CELD initiative. Robust internal verification systems were developed to ensure that the data being captured was authentic and evidence was collected for the indicators being reported against.

\subsection{Limitations}

This pilot intervention was part of a larger project to build an enabling environment for prioritizing RMNCHA and nutrition services in Uttar Pradesh. It evolved to address a felt need for monitoring, accountability and a feedback process for addressing roadblocks and building demand. Hence, this pilot was not evaluated using standard research methodology. However, the data sources quoted in the paper are based on the project MIS and have been validated by qualitative data points. Additionally, the pilot was implemented for a short period of about two years, due to which it was not possible to measure the long-lasting impact in service delivery due to the involvement and contribution of district and village elected representatives. Nevertheless, the trend captured by the robust internal MIS shows the potential of the strategy and the change it can bring about.

\section{RESUlTS \& DISCUSSION}

Salient achievements under the CELD initiative are:

- Nine months' post intervention, data collected as of 30 June 2019, shows that atleast $71 \%$ of GP are continuing to monitor the VHND session sites. Thus, the monitoring mechanism put in place is effective and sustainable.

- An increase of $15.5 \%$ for complete (four) ANC check-ups received by pregnant women over a period of one year was noted $\left[{ }^{17}\right]$ indicating an improvement in service delivery.

- Data as on 31 December, 2018 shows that 96.5\% of VHSNCs were activated and 91\% were conducting regular meetings as per the revised guidelines, of 330-90\% GP took initiative to strengthen health and nutrition services, $57 \%$ wrote 341 letters to political

[17] Based on the data extracted from HMIS. Source: HMIS, NHM GOI, Status As On: 23 Nov 2018, 2:06 PM, Period April to September, Financial Year: 2017-18 and 2018-19 leaders and district/block level officials for improving quality of services and 64\% made statements in media/ social media related to key issues pertaining to Reproductive, maternal, new-born and child health $[\mathrm{RMNCH}]$ and Nutrition.

- $91.2 \%$ VHND sessions in the intervention areas are conducting sessions as per the state guideline $\left[{ }^{18}\right]$ and $87.6 \%$ VHND sessions are providing complete VHND services.

- $76 \%$ VHND sessions were equipped to provide ANC check-up with privacy and in Lakhimpur Kheri 100\% VHND sites had ensured the provision of privacy. This important parameter led to more women attending ANC since their right to privacy was ensured. Privacy is an essential requirement for any physical examination, and as GHS also believes and promulgates the principle of Quality, Equity and Dignity (QED), this aspect was given adequate weightage. The monitoring data significantly captures increase in provision of private space and provision of a curtain for ANC.

- Overall 91\% VHND sessions have access to toilets, which can be attributed to the contribution of GP in ensuring privacy and functional toilet facilities at the session site in the intervention blocks. To ensure provision of services with dignity ensuring functional toilets at VHND sites was crucial, for collecting urine samples of pregnant women during ANC.

- Improved accountability of the frontline workers-FLWs (ANM, ASHA, Aanganwadi Worker) towards providing quality services during the VHND.

- 9 ANM vacancies were filled in three intervention blocks due to the active intervening by respective GP with government officials and advocating with the local political leaders (MP/MLAs).

- At least 16 meetings held post the introduction of block level interface

[18] Definition "As per state guideline": Session organized as per micro-plan; Availability of ASHA, AWW and ANM at session site; Immunization services are being provided to women \& children; Distribution of IFA tablets to women and adolescent girls; ANC services are being provided with privacy. 
platform with representation from health, ICDS and PRI departments and MP/MLAs and female \& male GP and 21 block level inter-departmental convergence meetings held.

- Oriented 144 religious leaders and $90 \%$ of them are disseminating key health and nutrition messages to the community

- At the National level, during a Members of Parliament Roundtable organized by GHS,
Smt. Anupriya Patel, Ex-Minister of State, Ministry of Health and Family Welfare, Government of India, Apna Dal, a request to organize a 'swasthya mela' (health camp) in each parliamentary constituency was put forth. This later led to the Issuance of the 'Nov. 2018-Health Mela Guidelines' by the Government of India along with budgetary support of Rs. 12 Lakh for each Lok Sabha constituency across India to organise health melas in their respective constituencies.

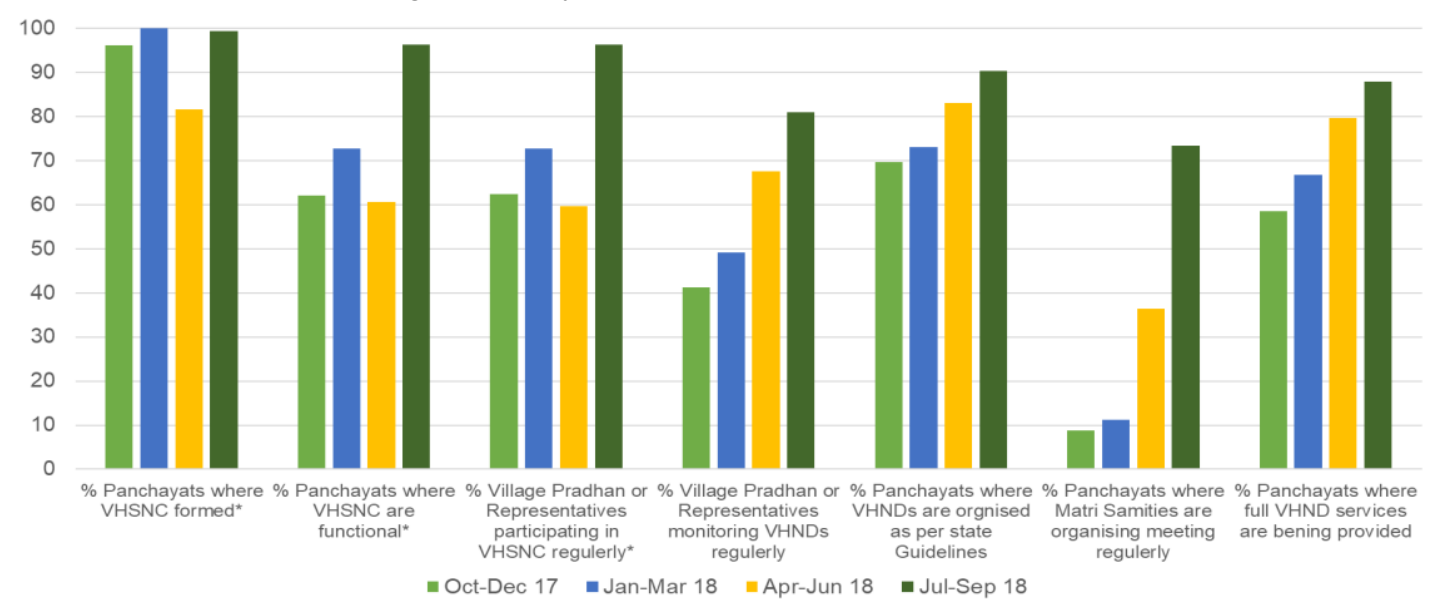

Figure1: Indicator wise analysis of Gram Panchayats

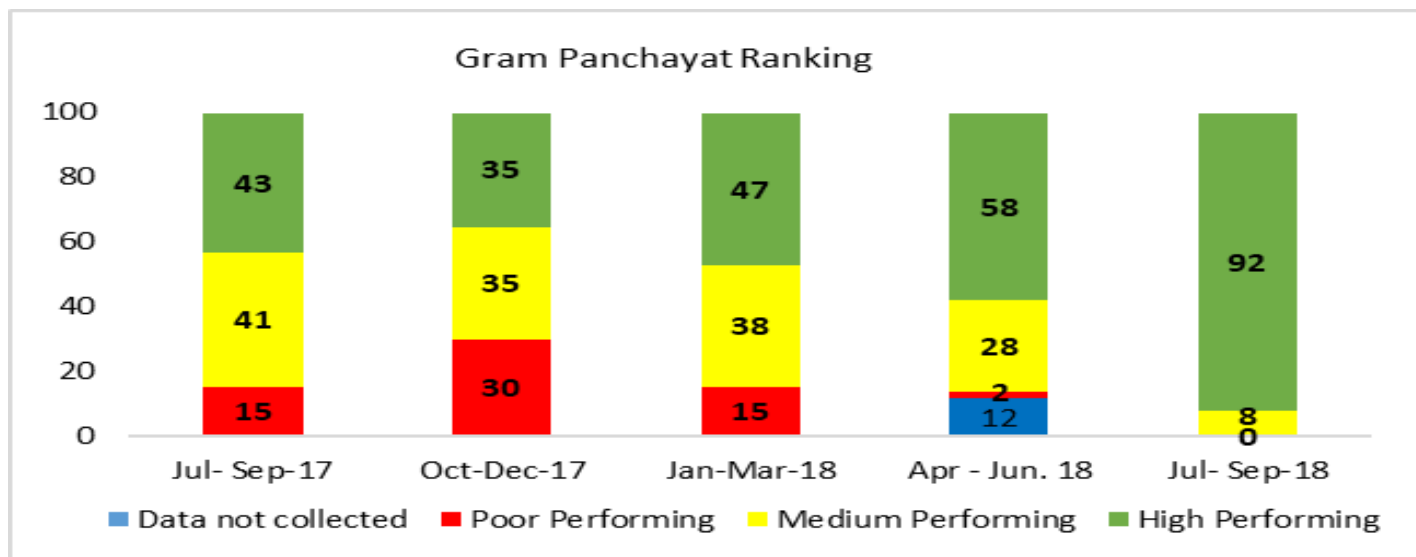

Figure2: Performance of Gram Panchayats of the intervention blocks, based on 10 performance indicators

- Figure: 1depicts the performance of the gram panchayats across key indicators.

- Figure:2 depicts the improvement over five quarters by a $49 \%$ increase, due to the efforts put in by the GP to improve the functioning of VHSNCs and VHNDs, which led to better quality of health and nutrition services at the community level.

\subsection{Special Focus on Women Gram Pradhans}

The CELD pilot focused on building capacity of women GP to understand their role and responsibilities towards advancing health and nutrition services in their villages.
The endeavour provided them with an opportunity to overcome deep-seated cultural resistance to catalyse change, by honing the ir skills and by addressing patriarchal mindsets. Though initially most of the women GP had a male representative who carried out all the tasks of a Gram Pradhan, the capacity building efforts under CELD motivated the women GP to take on important tasks like effective monitoring, to improve services themselves. However, the pilot was not able to measure the percentage increase of Women GP who started working independently, post capacity building, since the baseline data was not available. 
Improving Community Health and Nutrition Services: Role of Elected Leaders in Monitoring and Improving Service Delivery

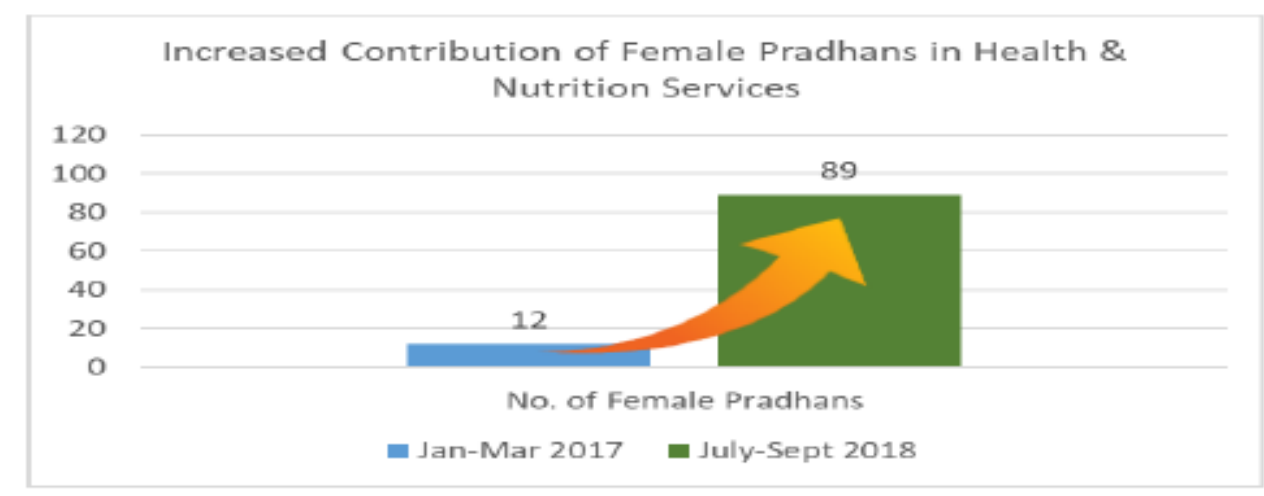

Figure3: Contribution of Female Gram Pradhans in Improving Health and Nutrition Services

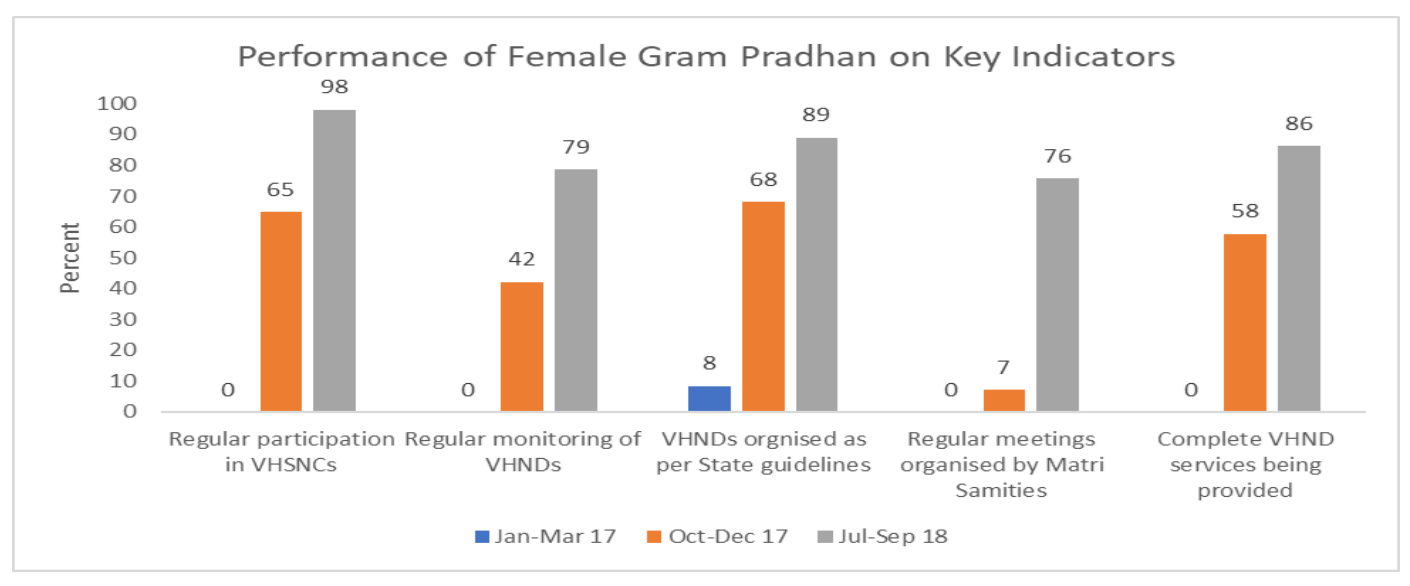

Figure4: Performance of Female Gram Pradhans on Key Indicators

Of the $330 \mathrm{GP}$ in the intervention areas 154 (47\%) were women GP, of which $16 \%$ worked independently without support of a male representative $\left[{ }^{19}\right]$. The CELD initiative was able to demonstrate a remarkable increase in Women GP taking the lead in monitoring VHND sessions and improving the quality of services being provided. Figure $\mathbf{3}$ clearly depicts a 7 fold increase in participation of Women GP i.e. a 50\%-point increase from initiation of the project to end of project (baseline $=8 \%$ endline $=58 \%$ )

This visible change against five key indicators is represented in Figure 4. At the initiation of the CELD initiative only one indicator was adhered to, i.e. only $8 \%$ of panchayats with a woman Gram Pradhan organized VHND sessions as per prescribed guidelines. Towards the last quarter of the project (July-Sept. 2018), nearly all women GP regularly participated in VHSNC meetings, $79 \%$ women GP started monitoring the VHND session sites using the checklist adapted from the govt. guidelines, an 81\%-point increase was seen in VHNDs being conducted

[19] Elected women gram pradhans who independently took on their role as elected representatives and did not have a male proxy. as per norms and $86 \%$ panchayats were providing complete VHND services.

A majority of the women GP steadily demonstrated a decreased dependence on their male representatives. By the end of the project, they relied on the representatives only for help with mobility/transport or completing tasks that required a higher level of literacy. This is reflected in the active participation by them in important activities; $58 \%$ women GP worked hands-on to improve health and nutrition services and resolve impediments to enhance implementation of schemes, $19 \%$ conducted rallies and disseminated key messages related to health and nutrition within the community they served, $29 \%$ wrote letters to relevant government officials and authorities on concerns that arose in their panchayats related to health and nutrition program implementation which primarily involved issues related to supplies of essential commodities, medicines etc., human resource gaps and performance, infrastructure for VHNDs, and untied funds disbursements. $25 \%$ of women GP conducted community meetings wherein they highlighted the importance of VHNDs, the need for early registration for $\mathrm{ANC}$ and complete ANC, benefits of family planning, full immunization 
of children, institutional delivery benefits, nutrition related key messages for new born, infants, children, pregnant and lactating women etc. A small number of women GP (4\%) also made statements in the media and participated on social media platforms to spread awareness about health and nutrition.

Some Women GP were felicitated at a State Level Symposium on RMNCH+A \& Nutrition-
Building a healthier UP, wherein the significant role of female elected representatives in strengthening health services and influencing behavior change at the community level, was specifically highlighted by a Member of Parliament. Figure- 5 shows the overall acievements under the intervention.

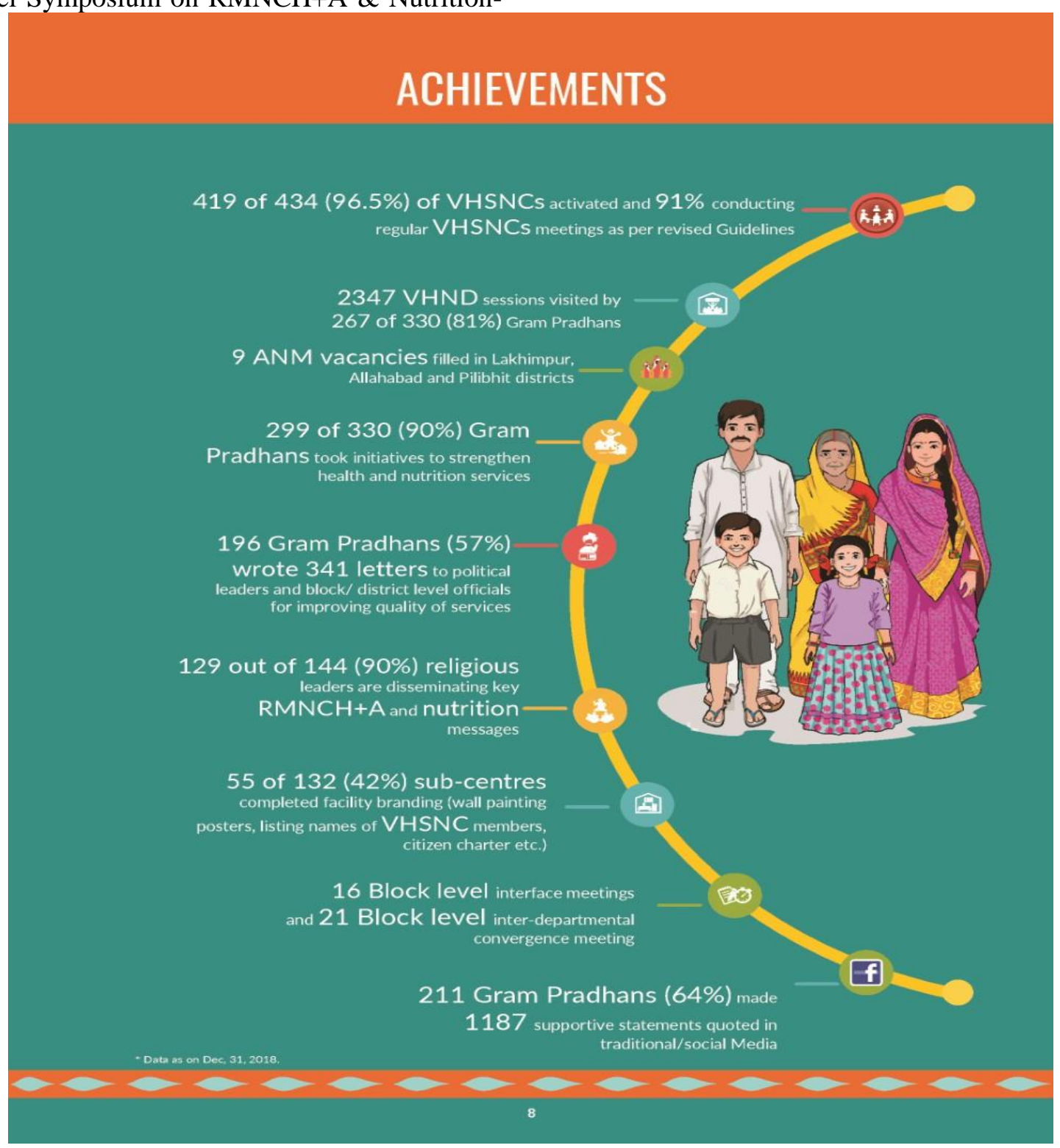

Figure5: Overall Achievements

The WHO underscores the importance of primary health care (PHC) as key to achieving Universal Health Coverage (UHC). The WHO UHC document also states that a key aspect is to "empower individuals, families, and communities to optimize their health, as advocates for policies that promote and protect health and wellbeing, as co-developers of health and social services through their participation, and as self-carers and care-givers to others" $\left[{ }^{20}\right]$.

Informing and engaging political and elected representatives was a key strategy of the project in prioritising RMNCHA and nutrition initiatives in the state of UP. Not only did this

[20]https://www.who.int/news-room/fact-sheets/ detail/universal-health-coverage-(uhc) 
ensure the smooth delivery of services but also built demand, trust and involvement of community representatives at the village level. Building models of two-way feedback mechanisms from grassroots to the state was also a key aspect to build accountability of officials and leaders.

\subsection{Some Key Learnings from the Project are}

While MPs/MLAs are aware of the state's poor health indicators, they did not understand the interlinkages between morbidity and mortality among women and children and the overall socio-economic development of society. Though many leaders were keen to work on improving the status of health and nutrition in their constituencies, they lacked the know-how on how policies and programs intersect to improve services and build demand. The team developed a responsive approach to address these gaps. This included a systematic process to engage, inform and build understanding of public health issues among political leaders. as well as outline solutions to address roadblocks and improve service delivery in their constituencies.

- Despite a slow start, the project team was able to build a core pool of champions among elected representatives at the state and village level. As the work progressed, the core pool expanded purely through 'word of mouth' recommendations by the representatives themselves.

- MPs are role models and social influencers. If they regularly mark their presence at the VHNDs, it will encourage the common village folk to come out in large numbers and participate. It will also help make the services being provided at the VHNDs more consistent, efficient, and help build the trust of the People in these services.

- Participation of elected village leaders has a great potential to address health and nutrition issues; however, it requires capacity building and hand holding especially on issues related to $\mathrm{RMNCH}+\mathrm{A}$ and nutrition and the interlinkages. In the present intervention, an attempt was made to develop the capacity of the GP and enable accountability mechanisms to enhance health and nutrition services. The initiative also demonstrated that GP, especially when linked with the MPs and MLAs, can be effectively engaged to promote awareness of health services, plan community needs assessment, carry out village level health activities and foster trust between the community and the health services. This linking up of political leaders, including women leaders, at the State and National level helps in creating a conducive environment and a chain of action at all levels.

- This pilot which was carried out over a period of about two years, showed interesting results and the potential for engaging elected representatives at all levels. However, it was not set up to measure population level impact. It is may be useful to have a project design with clear baseline and endline indicators to measure the real impact of monitoring and awareness messages by state, district and village elected representatives to improve community health and nutrition services.

\section{CONCLUSION}

The push towards greater efficiency of policies and platforms needs to be balanced by elements of effectiveness (accountability and transparency) that ensure inclusive growth and provision of services to all sections of society. Genuine decentralization through adequate devolution of power and resources to PRIs is essential particularly if we need to reap the maximum benefit within the limited resources at the village level. While this is admittedly a challenging task, elected representatives can play an important role.

Even though it is a pilot project in a relatively small area, the CELD initiative has shown that it is possible to motivate elected representatives to play an active role in ensuring and promoting community health. The initiative also proved that village institutions/platforms can become performance linked and there can be a marked improvement in streamlining redressal mechanisms, addressing stock-outs and giving positive health messages to build demand. Engaging elected representatives from state to village level has enabled a conducive environment for undertaking people-centric monitoring and improving demand and supply of health and nutrition services in a given area. This in turn has had a positive impact on prioritization of $\mathrm{RMNCH}+\mathrm{A}$ and nutrition issues at the state level and built a certain accountability towards the communities, with a definite impact on demand for these services. The monitoring mechanisms and convergence 
platforms established through the CELD model has been effective in addressing the systemic challenges at the block level. Measures such as working with the GP to monitor the ASHAs (frontline workers) for effective VHSNC and VHND functioning have made a compelling case for using village elected representatives as 'agents of change' to prioritize health and nutrition to the last mile.

The intervention outlined in this paper can enable India's community level platforms to transform themselves into institutions of good governance that are result oriented and provide quality and low-cost services to the community. This initiative was an experiment which garnered adequate interest and involvement among policy and decision makers, hence it needs to be further tested in other areas, preferably aspirational districts in UP. Since the results of this pilot intervention are encouraging, scaling-up this model pan UP, in the long run and measuring the impact, would help in achieving universal health care goals.

We believe, such initiatives contribute to healthsystems strengthening - something that is critical as the pandemic has shown us.

\section{ACKNOWLEDGMENTS}

The Government of India, through its many initiatives, has reiterated its commitment to improving maternal, newborn and child health services especially among vulnerable groups. Both the National Rural Livelihoods Mission and National Health Mission are focused on achieving universal access to equitable, affordable, and quality healthcare services that are accountable and responsive to people's needs both in rural and urban areas. With a mission to advance this vision, Global Health Strategies designed and implemented a comprehensive and multi-pronged strategy to create a conducive political and policy environment for improved awareness, access, and acceptance of $\mathrm{RMNCH}+\mathrm{A}$ and nutrition services, aimed at better health and nutrition outcomes in Uttar Pradesh. As part of this strategy, a salient component was the community-based engagement and leadership development (CELD) initiative that engaged and sensitized leaders at the grassroots level on strengthening village level platforms for enhancing access to health and nutrition services. Many policymakers, development partners, champions and project staff contributed substantially to the success of this endeavour.

We would like to extend our sincere gratitude to Bill and Melinda Gates Foundation teams who not only brought the much-needed focus on $\mathrm{RMNCH}+\mathrm{A}$ and nutrition, but tirelessly provided timely guidance and counsel. Implementing partners SATHI and Vatsalya paved the way with their arduous and tireless efforts and rendered tangible change in the state of UP. At the state level, the project received much needed support from Mission Director, National Health Mission, UP; Director, Department of Panchayati Raj; Director General, State Nutrition Mission and Director, ICDS. The team would also like to extend earnest gratitude to the elected representatives and political leadership in UP such as Prof Rita Bahuguna Joshi, MP, Prayagraj and Former Cabinet Minister, Government of UP, for her anchoring support throughout the project's tenure; Mr.Ajay Mishra, MP, Lakhimpur Kheri; Mr. Jawahar Lal Rajput, MLA Garautha, Jhansi; Mr. Rajmani Kol, MLA Koraon, Prayagraj; Mr. Bala Prasad Awasthi, MLA Dhaurhara, Lakhimpur Kheri; and Mr. Anil Kumar Dohrey, MLA Kannauj Sadar; for their undeterred support toward health and nutrition issues in the state. We thank all the gram pradhans and champions for reiterating that sustainable change is possible when we empower grassroots leadership. We are also grateful to all the Friends of UP coalition members for their unfeigned support and contributions to the CELD initiative. Block and district level authorities echoed our belief and played a salient role in auctioning ground-level changes. This effort would not have borne fruit without the support and commitment of the senior management of GHS and the State and field teams.

\section{REFERENCES}

[1] Dr. Jacob John., A Study on Effectiveness of Panchayati Raj Institutions in Health Care System in the State of Kerala, Kerala Development Society; Sponsored by Planning Commission Government of India November 2012.

[2] Abdul Ghaffar, Soumya Swaminathan, Anuradha Gupta, Stefan Swartling Peterson, David Bishai. BMJ Global Health, Vol. 4, Issue Suppl 8, Editorial Three-way partnerships fuel primary health care success; http://dx.doi.org/ 10.1136/bmjgh-2019-001579. 
Improving Community Health and Nutrition Services: Role of Elected Leaders in Monitoring and Improving Service Delivery

[3] Sapra, Ipsita (February 2013), "Living in the villages". Rural Democracy. Accessed from https://en.wikipedia.org/wiki/Gram_ panchayat, 26July, 2019.

[4] Handbook for Members of VHSNC, http:// nhsrcindia.org/sites/default/files/Handbook\%20 for $\% 20$ Members $\% 20$ of $\% 20$ VHSNC\%20$\% 20$ English.pdf.

[5] MONTHLY VILLAGE HEALTH NUTRITION DAY, GUIDELINES FOR AWWs/ASHAs/ANMs/PRIs, February 2007, NRHM 2005- 2012; Ministry of Health and
Family Welfare Government of India; http:// www.nrhmorissa.gov.in/writereaddata/Upload/ Documents/VHND_Guidelines.pdf.

[6] Farzana Afridi. Governance and public service delivery in India, April 2017; S-35407-INC-1, International Growth Centre.

[7] G. Narendra Kumar. An Institutional Framework for Good Governance in India; ASCI JOURNAL OF MANAGEMENT $34(1 \& 2), \quad 38-53$ Copyright (C) 2005 Administrative Staff College of India.

\section{ANNEXURE-1 (MONITORING CHECKLIST For GRAM PRADHAN)}

ग्राम स्वास्थ्य एवं पोषण दिवस हेतु ग्राम प्रधान के लिए अनुश्रवण प्रपत्र

\begin{tabular}{|c|c|c|c|}
\hline $\begin{array}{l}\text { जनपद: } \\
\text { उप स्वास्थ्य केन्द: } \\
\text { सत्र स्थल का नाम: }\end{array}$ & \multicolumn{3}{|c|}{$\begin{array}{ll}\text { ब्लाक: } & \text { सीएचसी/ पीएचसी: } \\
\text { ग्राम पंचायत: } & \text { ग्राम प्रधान का नाम: } \\
\text { दिवस:बुध/शनि(1/2/3/4/5) } & \text { भ्रमण का दिनांक व समय: }\end{array}$} \\
\hline क्र.सं & मापदंड & मूल्यांकन & टिप्पणी \\
\hline 1 & क्या सत्र संचालित हो रहा है ? यदि हाँ, तो सत्र पर - & हाँ/नहीं & \\
\hline क & ए०एन०एम० उपस्थित है: & हाँ/नहीं & \\
\hline ख & आंगनबाड़ी उपस्थित है: & हाँ/नहीं & \\
\hline ग & आशा उपस्थित है: & हाँ/नहीं & \\
\hline 2 & क्या आई०सी०डी०एस० विभाग के पर्यवेक्षक द्वारा सत्र का भ्रमण किया गया ? & हाँ/नहीं & \\
\hline 3 & क्या सत्र माइक्रोप्लान/रोस्टर के अनुसार निर्धारित दिन व स्थल पर आयोजित हो रहा है? & हाँ/नहीं & \\
\hline 4 & $\begin{array}{l}\text { क्या सत्र पर गर्भवती महिला एवं बच्चो को दी जाने वाली सभी टीके एवं सामग्री पर्याप्त } \\
\text { मात्रा में उपलब्थ है ? }\end{array}$ & हाँ/नहीं & \\
\hline 5 & $\begin{array}{l}\text { क्या सत्र पर उपलब्ध दवायें इस्तेमाल योग्य है ? (आआरएस,आयरन, केल्शियम, } \\
\text { पैरासिटामोल दवाओं की एवसपायरी तिथि जाँचे) }\end{array}$ & हाँ/नहीं & \\
\hline 6 & $\begin{array}{l}\text { क्या ए०एन०एम० के द्वारा टीकाकरण के पश्रात् लाभार्थियों को } 4 \text { महत्वपूर्ण संदेश एवं } \\
30 \text { मिनट तक रुकने की सलाह दी जा रही है ? }\end{array}$ & हाँ/नहीं & \\
\hline 7 & क्या गर्भवती महिलाओं की प्रसवपूर्व जाँच गोपनीयता के साथ किया जा रहा है ? & हाँ/नहीं & \\
\hline 8 & $\begin{array}{l}\text { क्या क्या सत्र स्थल पर उपलब्ध आला (स्टेयोस्कोप) एवं बी०पी०मशीन सही कार्य कर } \\
\text { रही है और गर्भवती महिलाओं का ब्लड प्रेशर (रक्तचाप) नापा जा रहा है ? }\end{array}$ & हाँ/नहीं & \\
\hline 9 & $\begin{array}{l}\text { क्या सत्र स्थल पर उपलब्ध वजन मशीन (गर्भवती महिलाओं एवं बच्चों के वजन हेतु) } \\
\text { सही कार्य कर रही है और वजन किया जा रहा है ? }\end{array}$ & हाँ/नहीं & \\
\hline 10 & $\begin{array}{l}\text { क्या गर्भवती महिलाओं में खून की कमी (एनीमिया) की पहचान के लिए खून की जांच } \\
\text { की जा रही है ? }\end{array}$ & हाँ/नहीं & \\
\hline 11 & क्या गर्भवती महिलाओं को लाल आयरन की गोली वितरित की जा रही है ? & हाँ/नहीं & \\
\hline 12 & $\begin{array}{l}\text { क्या सत्र स्थल पर पेशाब घर उपलब्ध व चालू अवस्था में है और गर्भवती महिलाओं की } \\
\text { पेशाब की जांच की जा रही है ? }\end{array}$ & हाँ/नहीं & \\
\hline 13 & क्या सत्र स्थल पर उपलझ्ध थर्मामीटर सही काम कर रहा है ? & हाँ/नहीं & \\
\hline 14 & $\begin{array}{l}\text { क्या बीमार बच्चों को डायरिया, निमोनिया या अन्य किसी बीमारी हेतु जांच एवं दवाई } \\
\text { वितरित की जा रही है ? }\end{array}$ & हाँ/नहीं & \\
\hline 15 & क्या महिलाओं/पुरूषों को परिवार नियोजन सम्बन्धित साथन वितरित किये जा रहे है ? & हाँ/नहीं & \\
\hline 16 & $\begin{array}{l}\text { क्या सत्र पर बीमार बच्चों/महिलाओं (गर्भवती, प्रसूता) को आवश्यकतानुसार रेफर } \\
\text { किया जा रहा है ? }\end{array}$ & हाँ/नहीं & \\
\hline 17 & $\begin{array}{l}\text { क्या आंगनवाड़ी कार्यकत्री द्वारा चिन्हित कुपोषित बच्चों को उपचार हेतु रेफर(संदर्भन) } \\
\text { और रेफर के पश्चात उनकी निगरानी सुनिश्चित की जा रही है ? }\end{array}$ & हाँ/नहीं & \\
\hline 18 & $\begin{array}{l}\text { क्या आंगनवाड़ी कार्यकत्री द्वारा } 6 \text { माह से } 3 \text { वर्ष किशोरियों,गर्भवती महिलाओं और } \\
\text { स्तनपान कराने वाली महिलाओं हेतु राशन दिया जा रहा है ? }\end{array}$ & हाँ/नहीं & \\
\hline 19 & क्या आंगनवाड़ी और आशा कार्यकत्री द्वारा लाभार्थियों की सूची बनाई गई है ? & हाँ/नहीं & \\
\hline 20 & $\begin{array}{l}\text { क्या आशा और आंगनवाड़ी लाभार्थियों को स्वास्थ्य एवं पोषण सत्र पर लाने के लिए } \\
\text { प्रेरित कर रही है ? }\end{array}$ & हाँ/नहीं & \\
\hline 21 & $\begin{array}{l}\text { क्या सत्र स्थल पर स्वास्थ्य एवं पोषण दिवस से सम्बन्धित किसी भी प्रकार की प्रचार- } \\
\text { प्रसार सामग्री प्रदर्शित की गई है ? }\end{array}$ & हाँ/नहीं & \\
\hline 22 & क्या सत्र पर लाभार्थियों/अभिभावकों को परामर्श/सलाह दी जा रही है ? & हाँ/नहीं & \\
\hline
\end{tabular}

1. *यदि कोई कार्यकता सत्र पर उपस्थित नही है तो उससे सम्बन्धित प्रश्रों में नहीं अकित करें।
2. नहीं उच्चर वाले प्रश्रों में टिप्पणी अवशय लिखें | टिप्पणी खाने में पर्याप्त जगह न होने पर प्रपन्न के पीछे विस्तार से लिख सकवे हैं।

ग्राम प्रधान का हस्ताक्षर

Citation: Anuj Ghosh. Improving Community Health and Nutrition Services: Role of Elected Leaders in Monitoring and Improving Service Delivery. ARC Journal of Public Health and Community Medicine. 2021; 6(2):9-20. Doi:doi.org/10.20431/2456-0596.0602002.

Copyright: () 2021 Authors. This is an open-access article distributed under the terms of the Creative Commons Attribution License, which permits unrestricted use, distribution, and reproduction in any medium, provided the original author and source are credited. 